\title{
Lessons from the Ghost of Salaryman Past: The Global Costs of the Breadwinner Imaginary
}

\section{ROBIN M. LEBLANC}

\begin{abstract}
A BOUT THE TIME OF the one-year anniversary of the March 2011 Tōhoku earthquake and tsunami, a conversation about the politics of nuclear power started up among Japanologists, mostly political scientists, on a listserv I read daily. The original discussion emerged from the question of whether Japanese political leaders would push for restarting a number of the offline nuclear power plants across the country in order to cover expected gaps in Japan's electricity supply. At first the debate's participants took up the countervailing pressures Japanese policymakers face: the need to provide affordable power to Japanese companies in order to spur economic recovery, the inevitable increase in greenhouse gas emissions that would be produced by a shift from nuclear to fossil fuels, the polling data suggesting an overwhelming majority of Japanese citizens are opposed to restarting the plants (Mainichi Shinbun 2012). Then the listserv debate broke away from scholarly assessments of the electoral and policy dilemmas faced by the ruling Democratic Party into thinly veiled arguments between proponents and opponents of nuclear power. Some assertions were made about the nuclear power "phobia" and "emotional" opposition of those who, it was suggested, do not understand the science of it, and a debate commenced over the question of how many people the Chernobyl accident of 1986 had really killed.

Finally, the listserv participants settled into an examination of which source of power, coal or nuclear, takes the most lives, when all the risks of coal extraction, air pollution, and such are matched against the likely frequency and scope of disasters of the sort that happened in Fukushima. Soon after this, the online discussion fizzled out. The conversation had, at any rate, lost its tone of collegiality, and the difficulty, especially for social scientists, of thinking through the probabilities associated with natural events on the scale of the Tōhoku earthquake and tsunami made the calculations of potential coal or nuclear casualties difficult to perform. Yet although I had never joined the debate myself, I had trouble moving my mind away from it. Something about it felt wrong to me, but I could not quite put my finger on what bothered me.
\end{abstract}


When I did fieldwork in a citizens' movement against a nuclear power plant, in 1999, long before the triple disasters of 3-11, I had several times heard one of the group's leaders, Baba-san, draw comparisons between coal and nuclear power. Rather than trying to sort out claims about which method of power generation was more dangerous, Baba was trying to draw my attention to the way advocates for all kinds of power generation silenced opponents by insisting upon the inevitability of individuals' sacrifices in return for the goods dependent upon electricity. Baba talked angrily about what he described as the countless lives sacrificed (giseisha) in prewar Japanese coal production. He then compared the lives lost to coal to the sacrifices asked of Japanese men who gave their lives on the battlefronts of World War II. Baba further insisted that the same logic that had been employed to justify the loss of men in dangerous coal mines or useless, fatal battles had been used in the postwar era to push men of his own generation into punishing hours of work on the factory floors of Japan's economic "miracle."

Baba expressed despite for the entire idea of noble sacrifice romanticized as manly duty; he said he hated the very word "gisei." He repeatedly pointed out that actual sacrifices were never evenly distributed among people. The powerful men who praised a masculine spirit of self-effacement were more likely to be the beneficiaries of others' sacrifices than to bear loss themselves, he said. As I recounted in the book I later wrote, despite the fact that he described himself as a man who could work for "all he was worth," Baba also said he hated words such as "kinbensa" (diligence) and "dōryoku" (effort), which are attached to the image of Japan's model middle-class "salaryman” worker (LeBlanc 2010, 148).

Baba said that praise of diligence and effort was only an attempt to get ordinary people, pressed simply to make a living, to give themselves up wholly into service of elites' desires to be ever richer and more powerful; new riches for a community did not necessarily mean better lives for all community members. According to Baba, at some point, a community must decide that it has enough, materially, to live well. Policymakers', power company executives', and local nuclear power plant supporters' insistence that Baba's town get over its "regional ego" and take on the potential risks of a nuclear power plant were, as Baba told it, simply attempts to get citizens to give into the logic and associated sacrifices required in the pursuit of unending growth.

Interestingly, the plant supporters whom Baba opposed also drew connections between the sacrifices demanded of coalminers, soldiers, and salarymen and the reasons why the town ought to accept a nuclear power plant. They differed with Baba only in their conviction that the risks and sacrifices were valuable and honorable. Localities must be willing to do their duty for the nation, one pronuclear interviewee told me. Nuclear power opponents are likely young mothers who do not really understand the issues, another suggested, implying that men would (or should) know better. Nuclear power was, plant supporters said on many occasions, necessary in resource-starved Japan to support the factories 
that provided the jobs for Japan's salarymen. In turn, the salarymen's work was essential to their families' well-being and to Japan's survival in a viciously competitive global arena.

A local referendum had documented the citizens' overwhelming opposition to a nuclear power plant a few years before I began my fieldwork. The central issue in the election I observed while conducting my fieldwork was whether the referendum's result would be enforced through the local government's official resistance to the plant plan or whether a strong pro-plant majority in the local assembly would be able to push the project through, despite voter opposition. Although the plant was clearly the dominant issue in the election, nearly every nuclear power-supporting candidate avoided mentioning nuclear power in his campaign literature, instead describing himself as "for economic revitalization." At the time, the use of the term "economic revitalization" struck me as an unethical and slippery way to avoid a public admission of support for the hugely unpopular project.

However, the pro-nuclear candidates might simply have insisted that economic revitalization was their real goal all along, the nuclear power plant only one on a long list of hard choices necessary to achieve that revitalization. I suspect if I went back to them today, even after the meltdown of the plants at Fukushima, many of the nuclear power proponents, like many of my listserv colleagues, would ask me to consider what other choices Japan really has. How else, they would want to know, will the local and national economies be able to grow again, to provide young men the jobs they need to start families, to buy homes, to revitalize a Japan where no one is having babies? They would not be alone. In at least one town where a nuclear power plant has been shut down in the wake of 3-11, citizens openly express worry about how their economy can possibly thrive without it (Kyōdō 2012).

I had these conversations more than a decade before the 3-11 disasters, and perhaps that is why I was uneasy remaining silent in the face of my listserv colleagues' debate. I felt I must have something relevant to bring to the discussion, but while my colleagues argued about whether the risks posed by plant design, Japan's geology, or weak regulatory structures could have been, should have been, or would eventually be surmounted, I was hung up on a different problem. I was stuck gnawing at the suggestion Baba made, more than a decade before 3-11, that the logic of "hard choices" in the pro-nuclear power rhetoric was somehow akin to the logic of sacrifice in war, that the mobilization of dedicated salarymen and that of soldiers was not so different, and I could not figure out how to make that point in the context of the argument among my scholarly colleagues.

An important part of why Baba disliked the rhetoric of the nuclear power supporters was that he thought it unfairly invoked notions of masculine duty and courage to make it difficult for men who wanted to think of themselves as good men to stand in opposition to it. The tone of the listserv discussion 
participants and the traded accusations of phobia and unrealistic optimism into which the debate so quickly dissolved reminded me of Baba's complaint about the valorization of manly sacrifice. At some point, it seemed to me that it was not any particular answer to the complicated technological, sociological, economic, political, or ethical questions of Japan's situation that was at stake in the debate, but rather a kind of intellectual manhood. Yet, I could not simply write off the online argument because it was one among experts, some of whom might well influence leaders in Japan and elsewhere on these issues, and because I heard similar debates unfold in conferences, over dinner tables I shared with colleagues, and among my students.

Whether among the Japanese citizenry or in the many post-Fukushima debates I have witnessed among my fellow social scientists, the rules of manhood tend to constrain critical thinking about nuclear power in Japan today, whether the individuals engaged in the discussion are male or not. Doubtless, that is in part because historically a culture of masculinity has helped to shape the cultures of academic and public discourse. But, more importantly, manhood matters because behind the nuclear power debate lurks an unarticulated but framing concern with whether the Japanese economy will allow workers (breadwinners) to feed their families. The breadwinner, habitually conceived of as the Japanese salaryman, is gendered male. This salarymanbreadwinner imaginary pushes the power-generation conversation back and forth between the polarizing dangers of nuclear power and economic decline. I think one reason that, at each pole of the debate, interlocutors summon up terms of critique that imply failed manhood, such as unwarranted idealism or unreasonable anxiety, is that, as they battle back their opponents' claims, they are thinking empathetically from a breadwinner's (male) position.

This bipolar debate is not completely without sense. Breadwinners do want and need to feed their families. But because the salaryman-breadwinner image is freighted with the contents of other symbol systems-Japan's modernity, its fit with the West, its place in a global economy frequently conceived within and outside of Japan as a vicious competition among nation-states-any debate that has a ghost of salaryman lurking in its corners also becomes strangely limited to a worldview in which nation-states are the appropriate object of analysis and in which the global economy is conceived of primarily in terms of interstate competition.

My point is not to theorize economies or economic discourse generally. I am not about to argue that it is wrong to take up economic policy questions with a view to their impact on the well-being of actual working people and those who depend upon them. I am not asking us to look at men's dominance over women. I am not trying to make an argument for or against nuclear power. I am not trying to offer Japan a path out of the 3-11 crises. The loss and displacement of tens of thousands of people in the wake of the triple disasters is an unspeakable tragedy, most of which, horribly, inescapably, must be managed 
on a one-by-one basis as individuals search out whatever it might be that will allow them to live on in some way despite the people and things that have been taken from them. The other crises - of political leadership, of energy production, of the economy, of the environment, of the growing numbers of underand unemployed youth, of hope-already existed. Right now I want to focus on the less-noticed constraints that ideas about manhood place on individuals' assumptions about what men's and governments' choices are.

What I want to do to is to provoke my readers into considering how frequently, in debates among scholars and laypeople of the late capitalist countries, assertions about what is necessary or inevitable for a nation rely, as Baba insisted was true about nuclear power debates, on unspoken assumptions about what is required to sustain a particular notion of manhood. In late capitalist countries, we still count on individual workers (breadwinners) to obtain and distribute the resources that sustain families, communities, and the opportunities and joys of life, despite the many ways in which the model fails in actuality. ${ }^{1}$ Japan's workforce is so highly sex-segregated that my claim that the breadwinner is imagined as a male salaryman is hardly controversial, but research by gender scholars around the globe suggests that, even with women's greater participation in the workforces of other rich countries, the imagined model worker is still a man, and thus is a construct likely to bring with it constraints of manhood similar to those we see in Japan. ${ }^{2}$

I want us to think about what it might be costing us to enter conversations about issues such as the public risks of nuclear power generation with unexamined presumptions about who might be the "regular" working people we are imagining justify our position. I want us to think through Japan's situation, and then I hope we will work together to determine what Japan's example might reveal more generally about what are or are not the relevant boundaries on policy debates.

In the case of Japan's current energy crisis debate, and in previous versions of it, the presumed needs of the model, male, white-collar breadwinner, or "salaryman," conception of the "regular person" has loomed large. If we do not dig down into the imagined masculinity of the breadwinner in the framework of discussions, such as the one about nuclear power, taking place among students of Japan right now, we cannot ask all the questions we should about how late

\footnotetext{
${ }^{1}$ The same might be true in many countries that we could not include among the group I here call "rich" nations, but for the sake of clarity in this short essay, I am sticking to the countries of Europe, North America, and Japan. Perhaps South Korea, Singapore, or Taiwan would fit as well, but they are very recent entrants to the "community" of wealthy nations. Taiwan's situation is further complicated by its ambiguous international status as not-fully-recognized nation-state.

${ }^{2}$ For evidence of how difficult it is to imagine women as family breadwinners even in the United States, which has a more fluid gendering of the work world than in Japan, we need only consult a recent BusinessWeek article about the identity challenges faced by men who have taken up childcare and housework to allow their wives' careers to advance (Hymowitz 2012).
} 
capitalist societies are organized or about how the community of late capitalist nations works (or fails to do so), whether for us, for nations, or for humanity in general. We cannot really total up the costs of nuclear or coal-based power generation or many other sorts of things we collectively do for and to our economies and societies.

\section{The Salaryman as a Soldier}

The salaryman, in a conservative business suit—with his "7 to 11" work hours, a commitment to his employer that won him the Japanese soubriquet kaisha ningen or "company human," and bowing solemnly as he gives and receives business cards — has come to seem quintessentially Japanese. He is so well associated with his nationality that he can be represented in American television and movies as if he is Japan. But the truth is, the salaryman, as his derivedfrom-English name implies, has always represented Japan's engagement with the West. In fact, the salaryman is only one of the more recent imaginations of Japanese manhood that has been constructed in a discursive community well aware of the global context of Japan's modern economy and politics.

From at least the time of the 1871 Iwakura Mission, in which important political leaders toured the United States and Europe in search of the means to place Japan on an equal footing with the West's encroaching imperialist nations, Japanese policymakers and pundits have pressed their countrymen to meet standards of manhood believed essential for keeping Japan abreast of competitors around the globe. Whether they have relied on the version of boys depicted in the translated American education texts used to develop Japanese elementary school curricula as early as the late nineteenth century, or the bearded, uniformed masculinity displayed in Emperor Meiji's portrait carefully modeled on Prussian military images, Japanese notions of manhood have been persistently defined within a consciousness of what manhood has been taken to be in the powerful North Atlantic countries (Frühstück and Walthall 2011; Osa 1999; Roden 2005; Yamazaki 2001). Even in contemporary self-help books, where readers see "post-racial" depictions of successful salarymen and get advice for how to negotiate dinners in Paris, doing manhood right is inextricably linked to developing "global savoir-faire" (Frühstück and Walthall 2011, 125). Of course, indigenous traditions of masculinity have been similarly valued, but whether in response to or in defiance of Western standards, according to military ideals or modern standards of economic competence, defining Japanese manhood has been one means of securing Japan's place in the international system (Mikanagi 2011, 76-89).

These days the Japanese salaryman is sometimes seen as stubbornly resistant to the changes Japanese firms need to make to compete in the dynamic global economy, but we should remember that until recently, both within and beyond 
Japan's borders, the salaryman was seen as one reason why, only a few decades after ignominious defeat in World War II, Japan had become an economic force with which the West must reckon. In popular discourse, salarymen have often been referred to as kigyō no senshi (corporate warriors), and that reference is intended to imply not only service to company but also, because corporate "warriors" are assumed to be in the business of making Japan economically powerful, service to nation. In the postwar era, the connection between salarymen and self-sacrificing service to company and country has been so strong that employers have invested in spiritual training courses for the salarymen; some employers have even looked directly to Japan's self-defense forces for training models that emphasize patience and endurance under great stress (Mikanagi 2011, 71-75).

In his now famous 1979 book Japan as Number One: Lesson for America, sociologist Ezra Vogel pointed to the hard-working "company man" as one of the key reasons Japan, a country "without natural resources," had dealt with the challenges of postindustrial society with a success that "astounded" him (viii). According to Vogel, Japan's model breadwinners prevented socially and economically destructive standoffs between employers and workers because of their "devotion to their company[ies]" (156). Through the employment scheme under which they worked, they delivered, relatively equally across society, the benefits of homeownership and modern conveniences, and, in doing this, they provided inspiration to the young $(191,197)$. Vogel ascribed the achievements of salarymen to the practice of corporate organization that made their choices of loyalty and hard work rational ones.

[The Japanese company] is successful not because of any mystical group loyalty embedded in the character of the Japanese race but because it provides a sense of belonging and a sense of pride to workers, who believe their future is best served by the success of their company. The pride and stability that so many Japanese have because a family member works in a large company helps stabilize the political process and set a tone for society at large. (157)

In the years since the publication of Japan as Number One, scholars have argued that other social structures, such as the labor force flexibility and unpaid care work provided by women, who were marginalized in the salaryman-focused corporation, helped to make this effective breadwinner model a possibility (see, e.g., Brinton 1993; Schoppa 2006). Some have drawn attention to the fact that large groups of men have never neatly fit the salaryman role (Roberson and Suzuki 2003).

As a number of gender scholars have noted recently, the "salaryman" identity of the middle-class, lifetime-employed corporate male breadwinner is, statistically speaking, in decline. The commitment of corporations to hire workers 
according to the salaryman model eroded over the past two decades of nearly stagnant economic growth. An increasingly large percentage of young men struggle to find positions in the workforce that approximate the salaryman status their fathers achieved (Brinton 2011). Far fewer men marry and become family breadwinners than was true a generation ago. Moreover, the salaryman is not simply a difficult identity to perform; it is a far less valued identity. Many young men simply do not aspire to be salarymen like those of their fathers' generation. Among young women it is fashionable to express despite for salarymen whom they imagine to be boorish, or, worse, chronically lecherous (Bardsley 2011; Horii and Burgess 2012). Tragically, even many salarymen themselves seem to be quite doubtful about who they are and what they represent. Mature men's suicide rates suddenly doubled in the economic crisis at the end of the 1990s and have stayed high (National Police Agency 2012).

Vogel argued, I think quite accurately, in 1979, that the salaryman's work ethic and job stability were the heart of Japan's postwar social welfare mechanism. "Even when Japan's growth far surpassed other countries and unemployment was virtually nonexistent, the Japanese employee sought workplaces that provided security and he exerted himself for his company, for public welfare was not a real alternative," he said (202). The private workplace now fails to provide this sort of stability for young people, but families have no clear alternatives to dependency upon the male breadwinner's family wage. The breakdown of the salaryman path to household well-being has contributed to the rise of inequality and poverty in Japan in recent years (Brinton 2011; Ōsawa 2010). Although these days actual salarymen are ever more rare, no newly imagined model worker has taken the salaryman's place. The ghost of the past salaryman is so central to the understanding of how Japan's late capitalism is supposed to work that replacing him with some new notion of who is "manning" the economy would mean a public admission that the national project of privatized self-sacrifice for the sake of the collective good is not working for some substantial portion of the population.

\section{UN-Cool BIZ}

The salaryman-breadwinner is still imagined as the model worker on whose shoulders the Japanese economy rests, but the risky business of keeping Japan going in a vicious global marketplace is often undertaken by someone else. No one embodies this truth better than the workers who manage the Fukushima meltdown site. Like self-effacing soldiers, they expose themselves to tremendous risk to do work that must be done for the good of the nation; but many also work

only as temporary workers, part of the growing body of Japanese men today who will never be recipients of the secure, esteemed jobs of real salarymen (Jobin 2011). Tellingly, although the Fukushima temporary contract workers enact 
the courage and display the work ethic that has long been associated with salaryman manliness, they get little attention in public discourse. Instead, the crisisrelated salaryman sacrifice that has received top billing is the "Cool Biz" campaign to change men's work wardrobes so that office buildings can raise the temperature setting on air conditioners in order to conserve energy. ${ }^{3}$

Cool Biz began as an initiative of Japan's Environment Ministry in 2005. Men were encouraged to take off their ties and leave their suit jackets at home during summer months so that their employers could turn up the air conditioning temperature and conserve energy, but it was not until the summer of 2011, when Japan confronted a shortage in the energy supply caused by the shutdown of nuclear power plants in the wake of the 3-11 triple disasters, that Cool Biz really gathered steam. In 2012, the campaign started in May, a month earlier than in the previous year, and it has expanded to include instructive fashion shows; "Super Cool Biz," a flamboyantly casual version prescribing "fun" cool clothing such as Hawaiian shirts; fashion industry efforts to capitalize on new clothing trends; and various forms of official rhetoric urging clients and customers visiting Cool Biz workplaces to be accepting of men's casual state of dress. The international media have joined the chorus, and Japanese Cool Biz is reported on around the globe. ${ }^{4}$

The Cool Biz campaign has many of the qualities of other weird stories that capture the attention of the Japanese and foreign media, such as high school girls' "compensated dates" with older men (Leheny 2006). Given the seriousness of Japan's energy crisis, a public uproar about a change in work wear seems like a silly distraction. However, what, at first glance, we might think could only be a trivial part of public debate about Japan's energy crisis—men's work wear-is, when examined further, powerfully instructive about the way in which important contemporary discussions of resources and the economy are enmeshed with the preservation of certain notions of manhood. Cool Biz may seem to be a far cry from the manipulation of masculine duty that Baba denounced more than a decade ago and quite different from the "man-up" standoff between proponents and opponents of nuclear energy with which I opened this essay. Yet, in its seemingly laughable elements, the growth of the Cool Biz campaign displays the importance of the salaryman imaginary to debates about how Japan ought to respond to the crisis of 3-11 and helps us to understand why, unless we challenge that imaginary, those debates will remain dangerously constrained.

Why is it that, in the face of the immensity of the Japanese energy crisis, the best leadership the government can provide is to suggest that men leave their ties and jackets at home? Why is it that, in one of the most literate and peaceful democratic nations on earth, men in the most secure white-collar jobs cannot

\footnotetext{
${ }^{3}$ Actually, "Cool Biz" was promoted by the government and elected officials for years, but it became an actual phenomenon only after 3-11 (Warnock 2012).

${ }^{4} \mathrm{~A}$ quick Google search of the term turns up an ever-growing world of Cool Biz imagery and related enterprises.
} 
be relied upon to choose garments appropriate to the temperature conditions they must endure at work? $?^{5}$ The answers to these questions lie in the rich historical and contemporary meaning of the Western-style men's business suits. The business suit is a marker of a Japanese male breadwinner's place in the country's white-collar workplace, which, as Vogel $(1979,157)$ pointed out, once produced the "pride and stability that so many Japanese have because a family member works in a large company." But perhaps even more important to the Cool Biz program, the business suit, with its associated and transnational connotation of masculine power, is also a marker of Japanese men's place in a globalized, technocratic, and masculine hierarchy that still "includes many remnants of colonial attitudes toward the developing world" (Connell 2005).

The large number of Japanese men who go to work in suits is both the result of the particular Japanese culture of the salaryman and yet globally legible as evidence of Japan's place as one of the "advanced countries" (senshin koku). Surrendering the suit under the pressures of Japan's limited energy resources, thus, is more than making a choice of which garment will be more comfortable in a sweaty office; it is also an unavoidable confrontation with Japan's limits in the global marketplace. If Japan's elite workers must dress as if they live in a country not yet developed enough to provide climate-controlled workspaces, then they may also have to ask themselves in what way Japan really differs from lesser-developed Asian nations that are not yet full members of the Western, "advanced" democracies club. ${ }^{6}$

The Cool Biz campaign discourse, which equates the relinquishment of the necktie with national service, leaves in place the figure of the self-sacrificing salaryman as the symbol of the Japanese economy, of regular people, of the spirit according to which the nation ought to buckle down to face the challenges ahead. The clothes of the salaryman might be changed, just as if he were a paper doll in the hands of a determined little girl. The salaryman's symbolic centrality to making the whole project of buckling down intelligible to Japan as a nation and of displaying-to Japan and among the other countries with which Japan competes for status - a Japanese man's capacity to do his duty is preserved. With the image of the salaryman sweating in an underlit office, Japan is resource poor but rich in spirit. Americans, bundled up all summer in their over-chilled work cubicles, still have lessons to learn.

Importantly, the Cool Biz business intensifies our focus on the needs of the breadwinners, who, depicted as sweating over their desks, trying awkwardly to make casual wear look professional, become again the protagonists of a noble

\footnotetext{
${ }^{5}$ Women, whose jobs are generally less important and less secure than those of men and whose work wardrobes are much more diverse and frequently changing, seem to be less central to and are perhaps less in need of the Cool Biz campaign.

${ }^{6}$ The importance to domestic politics of securing status among the elite Western nations and avoiding the stigma of backward or uncivilized the West has historically imposed on non-Western countries is lucidly explained by Ayșe Zarakol (2012).
} 
war against Japan's resource limitations, as they were in Vogel's Japan as Number One. The Cool Biz campaign praises sacrifice, but it also recasts "sacrifice" as something immensely more palatable than what those area residents or workers directly affected by the meltdown must endure. The courage required to go to work without a tie or to wear a tropical-style shirt to a meeting with a client is surely infinitely easier to muster than the courage required to set up a new life knowing one can never go home again or to take a very risky temporary job because the pay is good and steady work may not be in the offing again for a long time. The Cool Biz campaign functions also as a reminder that Japan's economy and thus Japan's earnest breadwinners are struggling desperately to get by without nuclear power and therefore highlights its essential contribution to the Japanese economy. Cool Biz has the effect of cheerfully keeping the postcrisis debate constrained within the "potential nuclear accident" and "economic decline" poles while the diligent salarymen-protagonists, shorn of the ties, suit coats, and even white collars that had marked them as men who belong to the global elite, help us to decide which of those poles is scariest.

When we consider the genesis of the salaryman-breadwinner-corporate warrior identity around which Cool Biz is focused, we must never forget that this manifestation of Japanese masculinity has deep roots in Japan's self-conscious engagement with Western traditions of masculinity over more than a century and a half. The suited breadwinner who requires a chilled office is not a weird Japanese invention; the Japanese salaryman imaginary is simply more self-consciously true to a masculine practice common throughout the developed world. The seemingly ridiculous redirection of a public debate about energy needs and the costs of various methods of meeting them into a men's fashion campaign points to the lingering power of the salaryman as Japan's model worker, even as actual salarymen - the loyal soldiers of equally loyal companies—fade into the past. This persistent ghost of a salaryman is costly for Japanese society because the lingering salaryman ideal obscures the real need for new visions of what Japan is or could be. This is true in areas of concern relatively distant from energy politics, such as the growth of inequality in the workforce or the way in which the calcification of the male model work image affects women, families, and the fertility rate. But perhaps more disturbing is the fact that, if we look carefully at who the salaryman was intended/assumed to be, we see that he is nothing other than an extraordinarily well developed model of the citizen-worker aspired to across the community of rich (mostly Western) nations.

\section{What the Salaryman Means for the Rest of Us}

What bothers me about Cool Biz and the energy-versus-growth focus in postcrisis discussions about Japan is the unconscious reliance on the notion that workers are soldiers in a nation's economic war and that the generation of 
power (and not just electricity) should also be considered from within that framework. The implicit frames slide too easily among levels of analysis. Men become metaphors for the nation-state; the advantage of nation-state is conceived as if it were analogous to the protection of a breadwinner and all who are dependent upon him. Then nation-states are imagined as independent entities, separate from other nation-states, just as the late-capitalist breadwinner is presumed to be his own welfare system. The focus on the effort of breadwinners to do what is necessary to keep their jobs - a focus on the obligations rather than the privileges that come with manhood-dampens our critical sense of the operations of power concealed in the idea of these obligations.

Seeing the earnest worker in the sweat-soaked shirt bent over his desk, we do not think to ask who he is and who_-so many of the young, so many women, so many elsewhere-do not get to be him both in Japan and around the world. Seeing his plight (a real one) we do not consider that, trapped though he is by duties as a breadwinner, he also is a bearer of costly privilege, of a way of life unavailable to many who provide resources for the systems to which he is obliged. Sympathetic to the weight of his duties, we fail to ask if the world he represents can be possible much longer. Understanding what the breadwinner needs, we see only the tradeoff between safety from nuclear risk and safety from economic decline. But that equation is far too narrowly conceived. We should be working with much bigger imaginations that stretch past the nation-state boundaries in conversations about economic growth, that stretch past the necessity of economic growth itself, that stretch past a way of organizing work that served rich country breadwinners (when, uncomplainingly, they served it) to something new, more possible over the long haul, and more human.

We smile condescendingly at Japan's men-who-have-given-up-suits as if the global community can actually afford for the real members of the rich nations' club to keep cold offices in midsummer. We pretend like we do not know what the suits mean, as if there is no racial joke when Japanese salarymen show up in a Mad Men episode. We do not say too much about the British Petroleum oil disaster in the Gulf of Mexico. We do not pause the risk-versus-growth, "hard choices" conversation long enough to ask for whom, exactly, the choices are hardest. We do not ask what other choices we are ignoring. Once we get stuck in a framework that owes debts to this sort of implicit vision, we consider Japan's energy policy decisions as if Japan alone, and not humanity in general, is resource poor, as if Japan alone, and not also the rest of us, must weigh the environmental costs of burning fossil fuels against those of radiation pouring into the air or sea, and as if we have nothing, as a global community, to gain or lose if some of Japan's rural people are persuaded to risk death or permanent displacement from their homes in order produce "clean" nuclear energy.

I want to provoke my readers into placing such debates in a bigger frame, into considering the possibility that Baba is right, that an insufficiently discussed 
notion of manly self-sacrifice delimits the boundaries of public imagination about the definition of and solution to the fundamental puzzles of well-being, not just in Japan, but in many countries. The salaryman, whose signature suit represents a vision of energy plenty that may be forever gone, is not Japan's mistake, not Japan's special problem, but rather evidence of the fullness with which the latecapitalist liberal democratic project has inhabited Japan. In the rich democracies, we are proud to have (at least in our dealings with each other) traded guns and camouflage for business suits and entrepreneurial initiative. However, for many of us, including scholars talking as scholars, the global economy is still a war, and our proud financiers, engineers, and men of commerce are still imagined to be men and still assumed to be soldiers. It is no wonder that my scholarly colleagues email-shout about power-production phobias and alternative counts of the coal and nuclear dead around the world. In war, a steady source of power is essential, even if lives must be given to gain it.

Twisted like a prism in the light, this economic war logic can come to look just shy of insane. Economic expansion (still deadly and, beyond the rich countries' borders, still involving lots of their soldiers and guns) has replaced territorial expansion as the goal of the men at the front. Meanwhile the public seems to demand even less justification for it than they did of the brutal projects of imperialism their countries pursued in the previous two centuries. That is because this war does not rely on patriotic support of a national army, which when it takes a man too long from his private life may become intolerable for him and his loved ones, but instead rests on the private commitment from and care for millions upon millions, perhaps billions, of mercenaries, working people imagined as typical male breadwinners who need jobs because others depend on them. The Japanese salaryman is perhaps the most intensified vision of that breadwinner-soldier in all of the rich world, even now when he is but a ghost of his former self. Nonetheless, I think if we look around we will see he is not alone. Other ghostly breadwinner-soldier models exist. They, too, are armies of individuals making do with jobs whose terms they do not define, accepting hard choices, doing their duty for home and nation, not thinking it is time to demand peace, or even anything else.

\section{List of References}

Bardsley, Jan. 2011. "The Oyaji Gets a Makeover: Guides for Japanese Salarymen in the New Millenium." In Manners and Mischief: Gender, Power, and Etiquette in Japan, eds. Jan Bardsley and Laura Miller. Berkeley: University of California Press.

Brinton, Mary C. 1993. Women and the Economic Miracle: Gender and Work in Postwar Japan. Berkeley: University of California Press. 
. 2011. Lost in Transition: Youth, Work, and Instability in Postindustrial Japan. New York: Cambridge University Press.

Connell, R. W. 2005. "Globalization, Imperialism, and Masculinities.” In Handbook of Studies on Men \& Masculinities, eds. Michael S. Kimmel, Jeff Hearn, and R. W. Connell. Thousand Oaks, Calif.: Sage Publications.

Frühstück, Sabine, and Anne Walthall. 2011. Recreating Japanese Men. Berkeley: University of California Press.

Horit, Mitsutoshi, and Adam Burgess. 2012. “Constructing Sexual Risk: 'Chikan', Collapsing Male Authority and the Emergence of Women-Only Train Carriages in Japan." Health, Risk \& Society 14(1):41-55.

Hymowitz, Carol. 2012. "Behind Every Great Woman.” Bloomberg BusinessWeek, January 4. http://www.businessweek.com/magazine/behind-every-great-woman-01042012.html\#p4 (accessed June 27, 2012).

Jobin, Paul. 2011. "Dying for TEPCO? Fukushima's Nuclear Contract Workers.” The Asia-Pacific Journal: Japan Focus 9(18/3). http://www.japanfocus.org/-Paul-Jobin/ 3523 (accessed on July 17, 2012).

KYōDō. 2012. "Hamaoka Plant Halt Leaves Locals in Economic Limbo." The Japan Times, May 30. www.japantimes.co.jp/print/nn20120530f3.html (accessed May 30, 2012).

LeBlanc, Robin M. 2010. The Art of the Gut: Manhood, Power, and Ethics in Japanese Politics. Berkeley: University of California Press.

Leheny, David Richard. 2006. Think Global, Fear Local: Sex, Violence, and Anxiety in Contemporary Japan. Ithaca, N.Y.: Cornell University Press.

Mainichi Shinbun. 2012. "Honsha yoron chōsa: ōi genpatsu no saikadō 'hantai' ha 63\%" [A Mainichi public opinion poll: 63\% oppose restarting Ōi nuclear power plant]. May 7. http://mainichi.jp/select/news/20120508k0000m040104000c.html (accessed June 30, 2012).

Mikanagi, Yumiko. 2011. Masculinity \& Japan's Foreign Relations. Boulder, Colo.: FirstForumPress.

National Police Agency, Government of Japan. 2012. "Heisei 23 nenjū ni okeru jisatsu no jōkyō" [Data for suicides in 2011]. http://www.npa.go.jp/toukei/index.htm (accessed May 29, 2012).

Osa Shizue. 1999. "Tenshi no jendā" [The gender of the emperor]. In Kyōdō kenkyū dansei ron [Cooperative research in masculinities theory], eds. Y. Nishikawa and M. Ogino. Kyoto: Jimbun shoin.

Ōsawa, Mari. 2010. “Saibunpai no jendā baiasu ga hinkon wo fukameteiru” [Gender bias in redistribution deepens poverty]. Gakujutsu no dōkō 15(9):52-54. http://dx.doi. org/10.5363/tits.15.9_52 (accessed June 28, 2012).

Roberson, James, and Nobue Suzuki. 2003. Men and Masculinities in Contemporary Japan: Dislocating the Salaryman Doxa. New York: Routledge.

Roden, Donald. 2005. “Thoughts on the Early Meiji Gentleman.” In Gendering Modern Japanese History, eds. Barbara Molony and Kathleen Uno. Cambridge, Mass.: Harvard University Asia Center.

Schoppa, Leonard. 2006. Race for the Exits: The Unraveling of Japan's System of Social Protection. Ithaca, N.Y.: Cornell University Press.

Vogel, EzRa. 1979. Japan as Number One: Lessons for America. Cambridge, Mass.: Harvard University Press.

Warnock, Eleanor. 2012. "It's Baaack! The Return of (Super?) Cool Biz." Wall Street Journal, April 27. 
Yamazaki, Hiroshi. 2001. "Kindai dansei no tanjō" [The birth of the modern man]. In Nihon no otoko ha doko kara kite, doko e yuku no ka [Japanese men: Where they came from, where they are heading], eds. H. Asai and S. Itō. Tokyo: Jūgetsusha.

Zarakol, Ay e. 2012. "Deviance, Abnormality and Stigmatization in International Relations." Paper presented at the Annual Meeting of the International Studies Association, San Diego, CA, April 1-4. 